\title{
Retinal nerve fiber layer loss documented by optical coherence tomography in patients with optic tract lesions
}

\author{
Perda da camada de fibras nervosas retinianas \\ documentada pela tomografia por coerência óptica \\ em pacientes com lesões do trato óptico
}

Mário Luiz Ribeiro Monteiro', Kenzo Hokazone²

\begin{abstract}
Purpose:To report abnormalities of retinal nerve fiber layer (RNFL) thickness using Stratus - optical coherence tomography (OCT) in two patients with optic tract lesions. Methods: Two patients with long standing homonymous hemianopia from optic tract lesions were submitted to a complete neuro-ophthalmic evaluation and to Stratus optical coherence tomography examination. Results: Both patients revealed diffuse loss of the RNFL at Stratus - OCT in both eyes. In the eyes with the temporal hemianopia, RFNL loss was diffuse but predominantly in the nasal and temporal areas of the optic disc, the classic pattern of band atrophy of the optic nerve. In the eyes with nasal hemianopia RNFL loss could be documented in the superior and inferior quadrants of the optic disc. RNFL loss correlated well with visual field loss and the expected pattern of RNFL loss in optic tract lesions. Conclusion : Stratus-Optical coherence tomography can provide useful information in the diagnosis of optic tract lesions by identifying the characteristic pattern of RNFL loss that occurs in both eyes in this condition.
\end{abstract}

Keywords: Retinal ganglion cells; Tomography, optical coherence; Visual pathways / abnormalities; Nerve fiber/ultrastructure; Diagnostic techniques, ophthalmological

\footnotetext{
'Livre-docente, Professor associado da Faculdade de Medicina da Universidade de São Paulo - USP - São Paulo (SP), Brasil; 'Médico colaborador do Setor de Neuroftalmologia da Divisão de Clínica Oftalmológica do Hospital das Clínicas da Faculdade de Medicina da Universidade de São Paulo - USP - São Paulo (SP) - Brasil.

Divisão de Clínica Oftalmológica do Hospital das Clínicas da Faculdade de Medicina da Universidade de São Paulo (USP). São Paulo (SP) - Brasil.
}

Recebido para publicação em: 12/1/2009 - Aceito para publicação em 1/2/2009 


\section{INTRODUCTION}

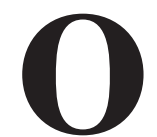
ptic tract lesions, although infrequently recognized, are of great importance because they represent the first region beyond the optic chiasm where lesions produce a homonymous hemianopia and because of its diagnostic implications. The etiologies are mostly primary tumors of the supraselar area such as cranyopharingeomas and pituitary adenomas but giant aneurysms, vascular processes, demyelinating disease and trauma can also occur. In most cases, the clinical findings are distinctive enough to establish a correct diagnosis: typically the patient has normal visual acuity in both eyes, a homonymous hemianopia contralateral to the lesion and a relative afferent pupillary defect in the eye with the temporal visual field defect ${ }^{(1,2)}$. Hemianopia may be complete or partial and when incomplete, the visual field defect is most likely incongruous, although vascular lesions may occasionally produce congruous optic tract hemianopia ${ }^{(3)}$.

Abnormalities in the retinal nerve fiber layer (RNFL) in long standing optic tract lesions are also characteristic. In such cases, there is a "wedge" or "band" of horizontal RNFL loss and pallor of the optic disc in the eye contralateral to the lesion (the eye with the temporal field loss) ${ }^{(1)}$. This pattern is caused by atrophy of the RNFL originating nasal to the fovea and is identical with that from chiasmal syndromes identified on ophthalmoscopy as band atrophy (BA) of the optic nerve ${ }^{(4,5)}$ At the same time, there is generalized pallor of the optic disc in the eye on the side of the lesion associated with severe loss of the RNFL in the superior and inferior arcuate lesions that comprise the majority of fibers originating from the ganglion cells temporal to the fovea. The RNFL loss may be evaluated on ophthalmoscopy as well as with several instruments including scanning laser polarimetry and optical coherence tomography.

Optical coherence tomography (OCT) is an in vivo technique for acquisition of cross-sectional images of retinal structures from which estimates of the thickness of retinal layers can be made. Several studies have documented the ability of OCT to demonstrate RNFL loss in eyes with BA of the optic nerve from chiasmal lesions $^{(6.8)}$ However, to our knowledge, only one previous study using an earlier version of the OCT instrument (OCT 1) has evaluated RNFL loss in optic tract lesions ${ }^{(9)}$. The purpose of this paper is therefore to demonstrate Stratus-OCT findings in 2 patients with optic tract lesions.

\section{Case reports}

Case 1:A 29-year-old man complained of left sided visual loss 4 years previously when he had a severe cranial trauma from a motorcycle accident. He was unconscious for a period of 10 days and noticed left sided visual loss as soon as he awoke and his visual deficit remained unchanged ever since. Ophthalmic examination revealed a visual acuity was 20/20 in each eye. Eye movements, slit lamp examination and intraocular measurements were normal. Pupils were equal in size and reactive to light and near stimulation. Swinging flashlight test revealed a + left relative afferent pupillary defect. Fundus examination showed diffuse optic disc pallor in the right eye (OD) and BA of the optic disc in the left eye (OS) (Figure 1). Visual field examination revealed a complete left homonymous hemianopia. In OD there was complete absence of the nasal hemifield and in OS a complete temporal hemianopia was present. (Figure 1). Stratus - OCT (Carl Zeiss Meditec, Dublin, California, USA) examination using a peripapillary fast retinal nerve fiber layer (RNFL) program, showed in the right RNFL thickness reduction at the superior and inferior quadrants while in the left eye a diffuse loss of RNFL most markedly in the temporal and nasal quadrants of the disc (Figure 1).

Case 2: A 23-year-old man presented with headache and was found on a routine eye examination to have pale optic discs. The patient was referred for neurologic investigation and a magnetic resonance imaging scan disclosed the presence of a large pituitary macroadenoma. After tumor discovery a left incongruous homonymous hemianopia was found on visual field examination. The tumor was surgically removed with slight improvement in visual fields. Six months after surgery he was examined by us and found to have best corrected visual acuity of 20/20 in both eyes. He had an incongruous left homonymous hemianopia with a hemianopic scotoma located in the nasal hemifield in $\mathrm{OD}$ and a temporal field defect in OS (Figure 2). Fundus examination revealed diffuse optic disc pallor in OD and BA of the optic nerve in OS. Stratus - OCT examination using a peripapillary fast retinal nerve fiber layer (RNFL) program, showed in the OD reduced RNFL in the superior and inferior quadrants while in the OS there was diffuse loss of the RNFL, most marked in the temporal and nasal quadrants of the disc (Figure 2).

\section{Discussion}

In our case Stratus -OCT demonstrated RNFL loss involving predominantly the nasal and temporal portions 

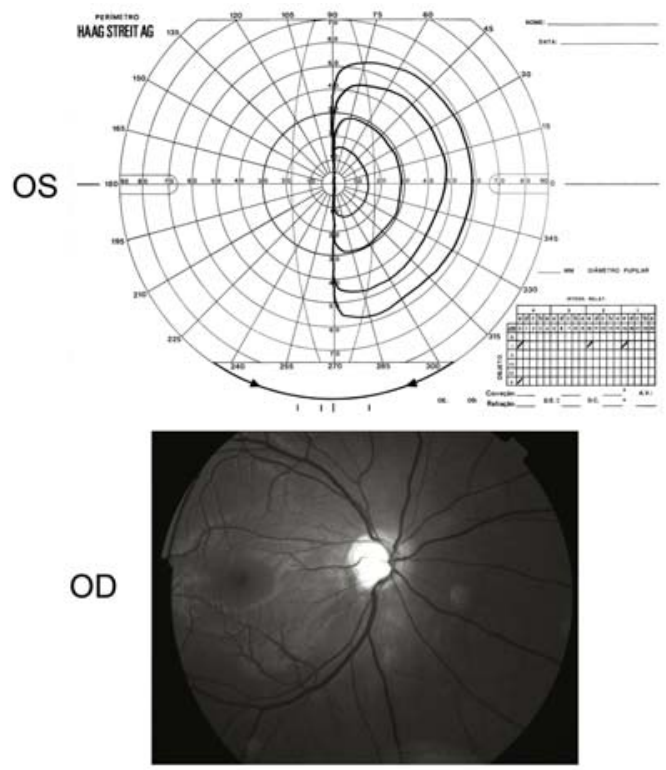
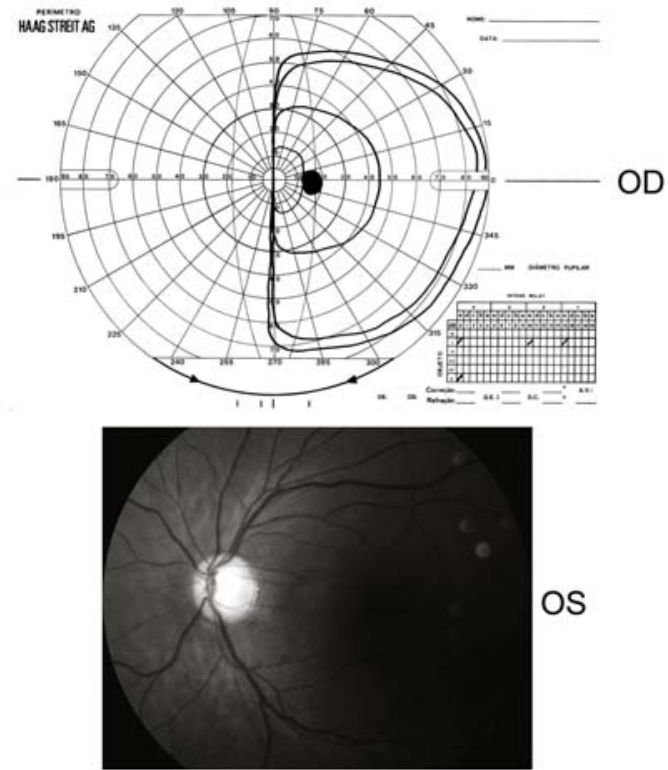

STRATUS OCT

RNFL Thickness Average Analysis Report - 4.0.1 (0056)

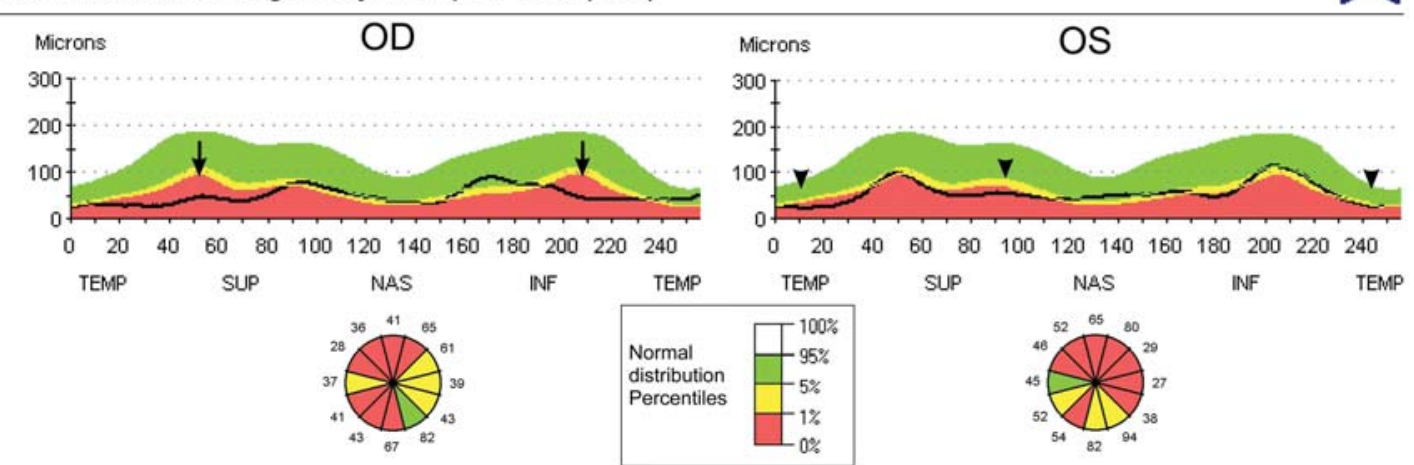

Figure 1: Case 1 - Goldmann visual fields showing complete left homonymous hemianopia. Middle, fundus photograph showing diffuse pallor in the right eye (OD) and band atrophy of the optic nerve in the left (OS). Below, Stratus - Optical coherence tomography showing retinal nerve fiber layer loss in the superior and inferior quadrant (arrows) in OD and in the temporal and nasal aspects of the optic nerve in OS (arrowheads)

of the disc, with relative preservation of the superior and inferior quadrants in the eye with temporal hemianopia. Such findings are in agreement with Midelberg and Yidegiligne's ${ }^{(10)}$ histological analysis of a patient with band atrophy and seems to confirm previous studies in patients with chiasmal compression and BA of the optic nerve ${ }^{(4-6,11)}$. However, our patient also serves to demonstrate the pattern of RNFL loss in the eye with the nasal hemianopia which has been the subject of only one previous publication ${ }^{(9)}$. In both eyes with the nasal hemianopia Stratus-OCT disclosed RNFL loss in the superior and inferior quadrants, documented loss of fibers originating from the temporal retina that enter the optic disc through the superior and inferior arcuate bundle fibers.
Our cases are interesting because confirm that OCT may be of help when investigating patients with homonymous hemianopia, since the associated occurrence of RNFL loss indicates the possibility of either and optic tract or a geniculate body lesion ${ }^{(12)}$ and rule out the possibility of optic radiation or occipital lobe diseases. Although clinical findings of optic disc pallor and a relative afferent pupillary defect in the eye with the temporal hemianopia can directly indicate the diagnosis of an optic tract lesion, the use of OCT may be of help when clinical findings are doubtful or difficult to obtain. While a good clinical evaluation of RNFL thickness has long been documented to be of importance in the diagnosis of optic tract lesion, the current findings are important to confirm the possible use of Stratus-OCT for quantifying 

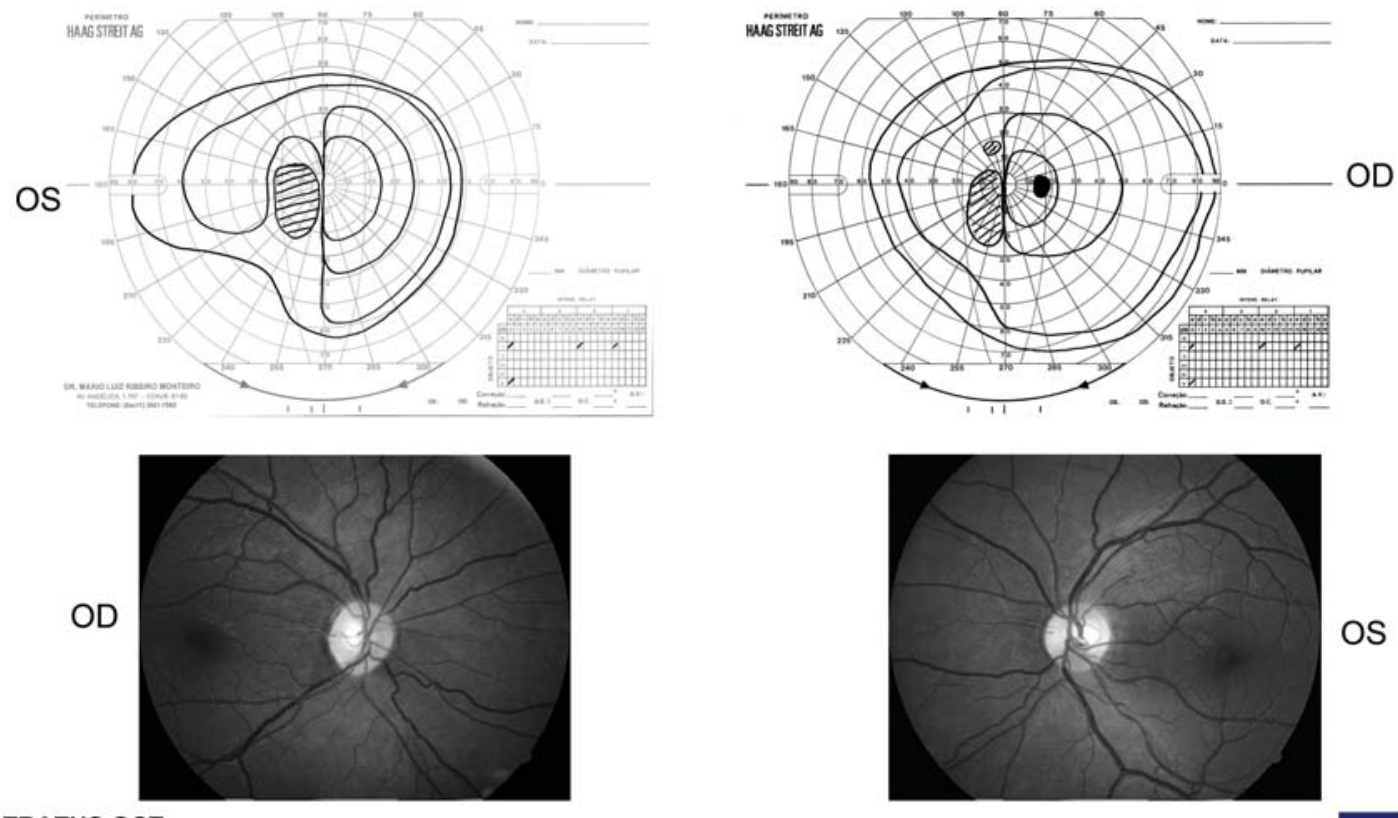

os
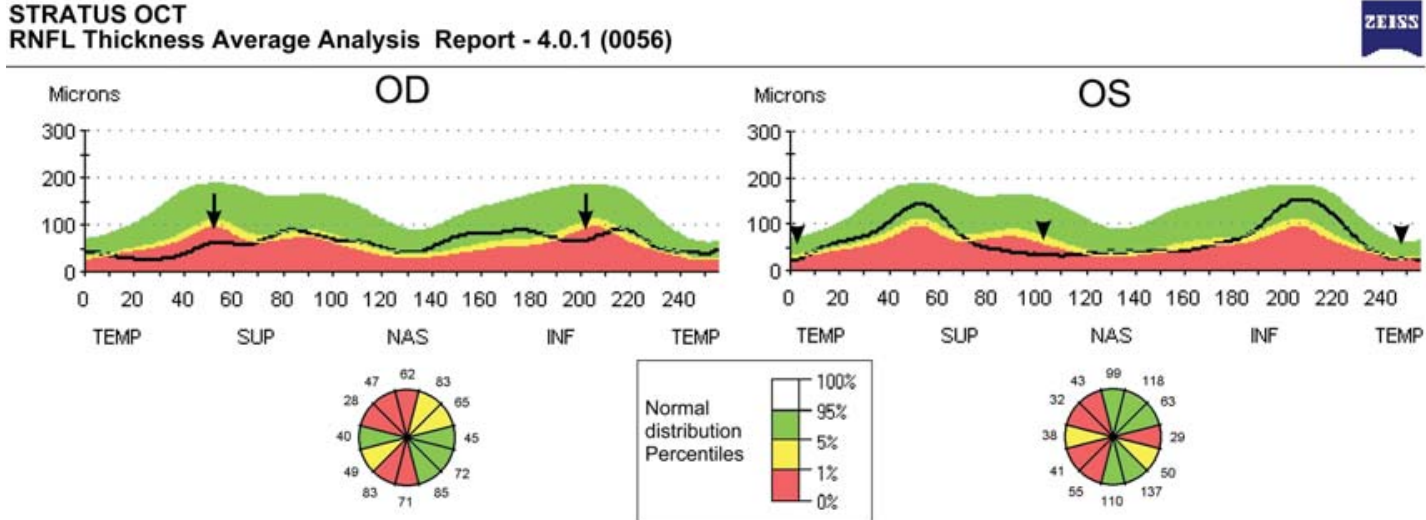

Figure 2: Case 2 - Goldmann visual fields showing incongruous left homonymous hemianopia. Middle, fundus photograph showing diffuse pallor in the right eye (OD) and band atrophy of the optic nerve in the left (OS). Below, Stratus - Optical coherence tomography showing retinal nerve fiber layer loss in the superior and inferior quadrant (arrows) in OD and in the temporal and nasal aspects of the optic nerve in OS (arrowheads)

RNFL in the diagnosis and management of patients with suspected or confirmed optic tract lesions.

\section{Resumo}

Objetivo: Relatar alterações na camada de fibras nervosas retiniana (CFNR) com o uso da tomografia por coerência óptica (TCO) Stratus em pacientes com lesões do trato óptico. Métodos: Dois pacientes com hemianopsia homônima de longa duração decorrente de lesões do trato óptico foram submetidos a avaliação neuroftalmológica completa e tomografia por coerência óptica Stratus. Resultados: Ambos pacientes demonstraram redução difusa da CFNR nos dois olhos. Nos olhos com a hemianopsia temoporal, a perda da CFNR foi difusa mas com predomínio nas áreas nasal e temporal do disco óptico, um padrão clássico da atrofia em banda do nervo óptico. Nos olhos com hemianopsia nasal observou-se perda da CFNR nos quadrantes superior e inferior do disco óptico. A perda da CFNR se correlacionou com o defeito de campo visual e com o padrão esperado de perda da CFNR nas lesões do trato óptico.Conclusão: A tomografia por coerência óptica - Stratus pode fornecer informação útil no diagnóstico das lesões do trato óptico ao identificar o padrão característico de perda da CFNR que ocorre em ambos os olhos nesta condição.

Descritores: Células ganglionares da retina, Tomografia de coerência óptica; Vias visuais/ abnormalidades; Fibras nervosas/ultraestrutura; Técnicas de diagnóstico oftalmológico 


\section{RefERenCES}

1. Newman SA, Miller NR. Optic tract syndrome. Neuroophthalmologic considerations. Arch Ophthalmol. 1983;101(8):1241-50.

2. Kardon R, Kawasaki A, Miller NR. Origin of the relative afferent pupillary defect in optic tract lesions. Ophthalmology. 2006;113(8):1345-53.

3. Kedar S, Zhang X, Lynn MJ, Newman NJ, Biousse V. Congruency in homonymous hemianopia. Am J Ophthalmol. 2007;143(5):772-80.

4. Monteiro ML, Medeiros FA, Ostroscki MR. Quantitative analysis of axonal loss in band atrophy of the optic nerve using scanning laser polarimetry. $\mathrm{Br} \mathrm{J}$ Ophthalmol. 2003;87(1):32-7.

5. Monteiro ML, Leal BC, Moura FC, Vessani RM, Medeiros FA. Comparison of retinal nerve fibre layer measurements using optical coherence tomography versions 1 and 3 in eyes with band atrophy of the optic nerve and normal controls. Eye. 2007;21(1):16-22.

6. Monteiro ML, Leal BC, Rosa AA, Bronstein MD. Optical coherence tomography analysis of axonal loss in band atrophy of the optic nerve. Br J Ophthalmol. 2004;88(7):896-9.

7. Moura FC, Medeiros FA, Monteiro ML. Evaluation of macular thickness measurements for detection of band atrophy of the optic nerve using optical coherence tomography. Ophthalmology. 2007;114(1):175-81.
8. Costa-Cunha LV, Cunha LP, Malta RF, Monteiro ML. Comparison of Fourier-domain and time-domain optical coherence tomography in the detection of band atrophy of the optic nerve. Am J Ophthalmol. 2009;147(1):56-63. e2.

9. Tatsumi Y, Kanamori A, Kusuhara A, Nakanishi Y, Kusuhara S, Nakamura M. Retinal nerve fiber layer thickness in optic tract syndrome. Jpn J Ophthalmol. 2005;49(4):294-6.

10. Mikelberg FS, Yidegiligne HM. Axonal loss in band atrophy of the optic nerve in craniopharyngioma: a quantitative analysis. Can J Ophthalmol. 1993;28(2):69-71.

11. Monteiro ML, Moura FC. Comparison of the GDx VCC scanning laser polarimeter and the stratus optical coherence tomograph in the detection of band atrophy of the optic nerve. Eye. 2008;22(5):641-8.

12. Moura FC, Lunardelli P, Leite CC, Monteiro ML. Hemianopsia por lesão no corpo geniculado lateral. Importância diagnóstica da análise da camada de fibras nervosas pela tomografia por coerência óptica: relato de caso. Arq Bras Oftalmol. 2005;68(6):860-3.
ENDEREÇO PARA CORRESPONDÊNCIA:
Mário Luiz Ribeiro Monteiro
Av. Angélica 1757 - Conj. 61
CEP 01227-200 - São Paulo - SP - Brasil
e-mail: mlrmonteiro@terra.com.br 